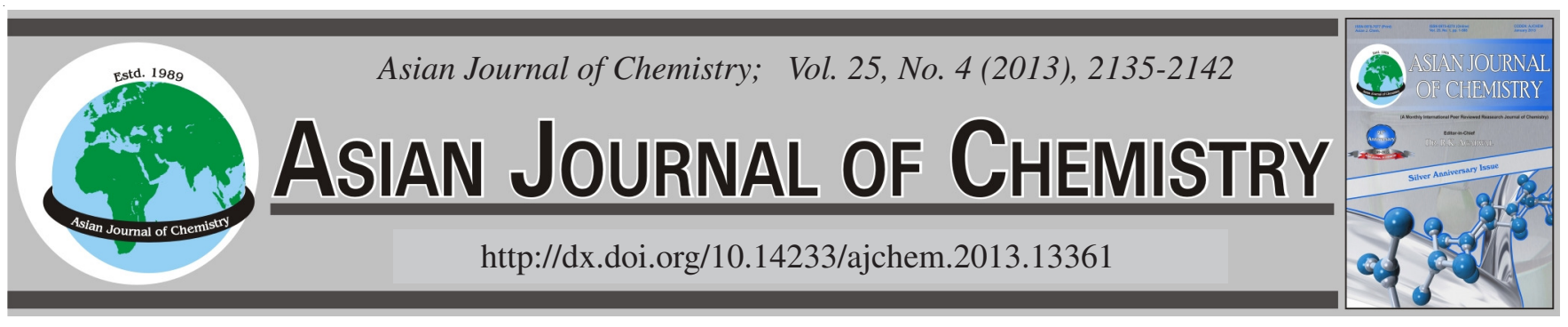

\title{
Latitude Effect on Carbon, Nitrogen and Oxygen Stable Isotope Ratios
}

\author{
HideMitSU KATSURA ${ }^{1,2, *}$
}

${ }^{1}$ The United Graduate School of Agricultural Science, Tokyo University of Agriculture \& Technology, Saiwai-Cho 3-Chome, Fuchu-Shi, Tokyo 183-8509, Japan

${ }^{2}$ Tokyo University of Marine Science and Technology, 5-7, Konan 4-Chome, Minato-ku, Tokyo 108-8477, Japan

*Corresponding author: Fax:+81 46754 1383; Tel: +81 46754 5869; E-mail: hi@katsura.dk

\begin{abstract}
Cosmic rays in the upper troposphere (30000 feet to 50000 feet; 9000 meters to 15000 meters) initiate the nuclear chemical reaction: ${ }^{1} \mathrm{n}+{ }^{14} \mathrm{~N}=>{ }^{14} \mathrm{C}+{ }^{1} \mathrm{H}$. Previous research has shown a strong effect of latitude on the abundance of neutrons from cosmic rays. However, to date, there has been little exploration of the relationship between the latitude effect for cosmic-ray neutrons and latitudinal variations of stable isotope ratios in aerosols and foliage. In this study, aerosol samples (PM 4.5) and foliage samples were collected in Singapore in November 2009, February 2010 and July 2010 and in Fairbanks, Alaska, U.S.A. in January 2010, April 2010 and September 2010. Ion chromatography, gas chromatography-mass spectrometry, and element mass spectrometry were used to measure anion concentrations and nitrogen and oxygen stable isotope ratios in nitrogen oxide ions of the aerosol samples, as well as to measure carbon and nitrogen stable isotope ratios in the foliage samples. The average value of $\delta^{15 / 14} \mathrm{~N}$ in foliage in Fairbanks was -1.84 [per mil], whereas the average value in Singapore was -1.3 [per mil]. These results show a clear latitude effect on $\delta^{15 / 14} \mathrm{~N}$ in foliage. Furthermore, the average value of $\delta^{15 / 14} \mathrm{~N}$ in the nitric-oxide substances in the aerosol samples in Fairbanks was -2.70 [per mil], whereas the average value in Singapore was +7.61 [per mil], demonstrating that $\delta^{15 / 14} \mathrm{~N}$ in nitric-oxide substances from aerosol samples also experiences a latitude effect. However, no clear latitudinal pattern was observed for $\delta^{13 / 12} \mathrm{C}$ in foliage or for $\delta^{18 / 16} \mathrm{O}$ in nitric-oxide substances from aerosols. In both Singapore and Fairbanks, it was observed that values of $\delta^{15 / 14} \mathrm{~N}$ in nitric-oxide substances from aerosols were correlated with declination. The value of $\delta^{15 /}$ ${ }^{14} \mathrm{~N}$ in nitric-oxide substances from aerosols in Fairbanks increased with increasing declination due to more active conversions from ${ }^{14} \mathrm{~N}$ to ${ }^{14} \mathrm{C}$ by neutron bombardment.
\end{abstract}

Key Words: Latitude effect, PM 4.5 aerosol, $\delta^{13} \mathrm{C} /{ }^{12} \mathrm{C}$ Isotope ratios, $\delta^{15} \mathrm{~N} /{ }^{14} \mathrm{~N}$ Isotope ratios, $\delta^{18} \mathrm{O} /{ }^{16} \mathrm{O}$ Isotope ratios.

\section{INTRODUCTION}

The analysis of stable isotopes can provide important insights into many aspects of the global environment, including mechanisms relevant to climate change, such as the geochemical behaviour of aerosols and the functions of foliage ${ }^{1-3}$. Relatively little is known about latitudinal differences in stable isotopes of nitrogen and oxygen occurring in nitric-oxide substances from aerosols or about the concentration of anions in aerosols. Knowledge about the latitudinal effects of carbon and nitrogen in foliage on stable isotopes is also limited. Cosmic rays provide a mechanism for such latitudinal effects. In the upper troposphere (30000 feet to 50000 feet; 9000 meters to 15000 meters), cosmic rays initiate the following nuclear chemical reaction ${ }^{4}$ :

$$
{ }_{0}^{1} \mathrm{n}+{ }_{7}^{14} \mathrm{~N} \rightarrow{ }_{6}^{14} \mathrm{C}+{ }_{1}^{1} \mathrm{H}
$$

Previous research has shown a strong effect of latitude on the abundance of neutrons from cosmic rays ${ }^{5}$. However, to date there has been little exploration of the relationship between the latitude effect for cosmic-ray neutrons and latitudinal variations of stable isotope ratios in aerosols and foliage. This study aimed to investigate this relationship by comparing aerosol and foliage samples from an equatorial region (Singapore) and a sub-polar region (Fairbanks, Alaska, U.S.A.). Aerosol samples (PM 4.5) and foliage samples were collected at the National University of Singapore (NUS) in Singapore (latitude: $1^{\circ} 18^{\prime} \mathrm{N}$; longitude: $103^{\circ} 46^{\prime} \mathrm{E}$; altitude: 67.0 meters) from 16 to 22 November 2009, 08 to 20 February 2010 and 16 to 28 July 2010 and at Fairbanks International Airport in Fairbanks, Alaska, U.S.A. (latitude: 6450.116'; longitude: $147^{\circ} 49.747^{\prime} \mathrm{W}$; altitude: 143.3 meters) from 02 to 05 January 2010, 01 to 09 April 2010 and 21 to 27 September 2010. Anion concentrations in the aerosol samples were analyzed by ion chromatography and nitrogen and oxygen stable isotope ratios were analyzed by gas chromatography-mass spectrometry. Carbon and nitrogen stable isotope ratios in foliage were analyzed by element mass spectrometry. The objective of this study was to elucidate how the latitude effect on neutron 
bombardment from cosmic rays affects the isotopic characteristics of aerosols and foliage.

\section{EXPERIMENTAL}

Aerosol samples (PM 4.5) were taken at the rooftop of Building E2 at the National University of Singapore in Singapore (latitude: $1^{\circ} 18^{\prime} \mathrm{N}$; longitude: $103^{\circ} 46^{\prime} \mathrm{E}$; altitude: 67.0 meters) from 15:27 SGT (Singapore Time $=$ SGT $=$ UTC + 7 h) 16 to 15:27 SGT 17 November 2009; from 15:39 SGT 17 to $15: 39$ SGT 18 November 2009; from 15:42 SGT 18 to 15:42 SST 19 November 2009; from 18:18 SGT 19 to 18:18 SGT 20 November 2009; from 18:35 SGT 20 to 18:35 SGT 21 November 2009; from 19:08 SGT 21 to 19:08 SGT 22 November 2009; from 17:09 SGT 08 to 17:09 SGT 12 February 2010; from 17:12 SGT 12 to 17:12 SGT 16 February 2010; from 17:13 SGT 16 to $17: 13$ SGT 20 February 2010; from 13:22 SGT 16 to 13:22 SGT 20 July 2010; from 13:25 SGT 20 to 13:25 SGT 24 July 2010; and from 13:25 SGT 24 to 13:25 SGT 28 July 2010. A sampling pump (Model SP 250, GL Science) was operated at the rooftop for sample extraction and the samples were collected onto polyamide filters (NX047100, Pall Corporation) at a flow rate of $5 \mathrm{~L} / \mathrm{min}$.

Aerosol samples (PM 4.5) were taken at Fairbanks International Airport in Fairbanks, Alaska, U.S.A. (latitude: 64 $4^{\circ} 50.116^{\prime} \mathrm{N}$; longitude: $147^{\circ} 49.747^{\prime} \mathrm{W}$; altitude: 143.3 meters) from 14:14 AST (Alaska Standard Time = AST = UTC -9 h) 02 to 14:14 AST 03 January 2010; from 14:17 AST 03 to 14:17 AST 04 January 2010; from 14:21 AST 04 to 14:21 AST 05 January 2010; from 17:11 ADT (Alaska Daylight Saving Time $=$ ADT $=$ UTC -8 hours) 01 to 17:10 ADT 03 April 2010; from 17:12 ADT 03 to 17:12 ADT 05 April 2010; from 17:14 ADT 05 to 17:14 ADT 07 April 2010; from 17:16 ADT 07 to 17:16 ADT 09 April 2010; from 10:10 ADT 21 to 10:10 ADT 23 September 2010; from 10:12 ADT 23 to 10:12 ADT 25 September 2010 and from 10:14 ADT 25 to 10:14 ADT 27 September 2010. A sampling pump (Model SP 250, GL Science) was operated at the 2nd floor terrace of a lodge (Golden North Motel; 4888 Old Airport Road, Fairbanks, Alaska 99709, U.S.A.) at Fairbanks International Airport in Fairbanks, Alaska, U.S.A. and the samples were collected onto polyamide filters (NX047100, Pall Corporation) at a flow rate of $5 \mathrm{~L} / \mathrm{min}$.

Each polyamide filter was then transferred into $20 \mathrm{~mL}$ of ultrapure water and shaken for $c a$. $40 \mathrm{~min}$. The extracts were filtered and analyzed using an ion chromatography (DX 120/ AS, Dianex Inc.).

The $\delta^{15} \mathrm{~N} /{ }^{14} \mathrm{~N}$ and $\delta^{18} \mathrm{O} /{ }^{16} \mathrm{O}$ isotope ratios in $\mathrm{NO}_{3}{ }^{-}$were measured using the denitrifier method ${ }^{6,7}$. The $\mathrm{NO}_{3}{ }^{-}$was converted to $\mathrm{N}_{2} \mathrm{O}$ using a denitrifier (Pseudomonas aureofaciens; ATCC 13985) lacking $\mathrm{N}_{2} \mathrm{O}$ reductase. The $\mathrm{N}_{2} \mathrm{O}$ was then introduced into a $\delta$-XP isotope ratio mass spectrometry coupled to an HP6890 gas chromatography (Hewlett-Packard Co., Palo Alto, CA, U.S.A.) equipped with a PoraPLOT column and a GC interface III (Thermo Fisher Scientific). Anion concentrations and isotope ratios were measured at the Laboratory of Social Biogeochemistry (Laboratory of Professor Muneoki YOH \& Associate Professor Keisuke KOBA), Tokyo University of Agriculture \& Technology (TUAT), Building \#2, Rooms
$328 \&$ 2N-101, 5-8, Saiwai-Cho 3-Chome, Fuchu-Shi, Tokyo 183-8509, Japan. The calibration curves for these isotopic analyses were constructed using the international standards USGS32, USGS34, USGS35 and IAEA. The stable isotope ratio $\delta$ was calculated with the following equation ${ }^{8}$.

$$
\left[\frac{\text { RSAMPLE }- \text { RSTANDARD }}{\text { RSTANDARD }}\right] \times 1000 \% \%=\delta=\text { delta }
$$

Abies firma (Momi or Japanese fir) was selected as the source of foliage samples in Fairbanks, Alaska, U.S.A. This species is a typical forestry tree in the Fairbanks region. Samanea saman (rain tree) was selected as the source of foliage samples in Singapore. It is a typical forestry tree in Singapore. Sampling was performed on 05 January 2010, 07 April 2010, 22 September 2010, 23 September 2010 and 25 September 2010 in Fairbanks Alaska, U.S.A. and on 16 February 2010, 18 February 2010, 24 July 2010 and 27 July 2010 in Singapore.

In the laboratory, collected foliage was dried at $80{ }^{\circ} \mathrm{C}$ to constant weight. All foliage samples were ground using a ball mill (MM200; Retsch GmbH and Co. KG, Haan, Germany). Ground samples were analyzed for $\delta^{15 / 14} \mathrm{~N}$ and $\delta^{13 / 12} \mathrm{C}$ using an elemental analyzer (EA1112; Thermo Fisher Scientific K.K., Yokohama, Japan) coupled with a Delta-XP isotope ratio mass spectrometry (Thermo Fisher Scientific K.K.). Calibrated DL$\alpha$-alanine $\left(\delta^{13 / 12} \mathrm{C}=-23.45\right.$ [per mil]; $\delta^{15 / 14} \mathrm{~N}=-1.66$ [per mil] $)$, glycine $\left(\delta^{13 / 12} \mathrm{C}=-34.89\right.$ [per mil]; $\delta^{15 / 14} \mathrm{~N}=10.04$ [per mil]) and histidine $\left(\delta^{13 / 12} \mathrm{C}=-9.94\right.$ [per mil]; $\delta^{15 / 14} \mathrm{~N}=-7.96$ [per mil] $)$ were used as internal standards. The stable isotope ratio $\delta$ was calculated $^{8}$ using eqn. 2.

\section{RESULTS AND DISCUSSION}

Table-1 shows the statistics of the inorganic anion concentrations and the stable isotope ratios in the nitric-oxide substances within the aerosol samples for all the samples collected in Singapore during this study (Table-1). Table-2 shows the same data for Fairbanks, Alaska, U.S.A. For both sampling locations, Table-3 shows the following: sampling place, date and time; declination; maximum and minimum temperature; day length; stable isotope ratios in the nitricoxide substances the aerosol samples; and carbon and nitrogen stable isotope ratios in the foliar samples.

It is generally known that $\delta^{15 / 14} \mathrm{~N}$ in foliage decreases with increasing latitude ${ }^{9}$. It was found that the average value of $\delta^{15 /}$ ${ }^{14} \mathrm{~N}$ in foliage in Fairbanks (latitude $64.84^{\circ} \mathrm{N}$ ) was -1.84 [per mil] whereas the average value of $\delta^{15 / 14} \mathrm{~N}$ in foliage in Singapore (latitude $1.3^{\circ} \mathrm{N}$ ) was -1.3 [per mil] (Table-3), clearly following the expected trend. However, no such latitudinal trend was apparent for $\delta^{13 / 12} \mathrm{C}$ in foliage: in Fairbanks the average value was -23.18 [per mil] and in Singapore the average value was -24.1 [per mil] (Table-3). Trends for $\delta^{15 / 14} \mathrm{~N}$ in aerosols were similar to those in foliage: the average value of $\delta^{15 / 14} \mathrm{~N}$ in the nitric-oxide substances within the aerosol samples in Fairbanks was -2.70 [per mil], whereas in Singapore the average value was +7.61 [per mil] (Table-3), showing a clear increase with decreasing latitude. However, $\delta^{18 / 16} \mathrm{O}$ in aerosol samples did not show a latitudinal trend: the average value of $\delta^{18 / 16} \mathrm{O}$ in the nitric-oxide substances within the aerosol samples in Fairbanks 
TABLE-1

STABLE ISOTOPE RATIOS AND ANION CONCENTRATION OF AEROSOL (PM $=4.5)(5 \mathrm{~L} / \mathrm{min})$ AT

NATIONAL UNIVERSITY OF SINGAPORE IN SINGAPORE, FROM 16 NOV 2009 TO 28 JUL 2010

\begin{tabular}{|c|c|c|c|c|c|c|c|c|}
\hline $\begin{array}{c}\text { Sampling Date and time } \\
(\text { Singapore Time }=\text { SGT }=\text { UTC }+8 \mathrm{~h})\end{array}$ & $\begin{array}{l}\delta^{15} \mathrm{~N} /{ }^{14} \mathrm{~N} \\
{[\text { per mil] }}\end{array}$ & $\begin{array}{l}\delta^{18} \mathrm{O} /{ }^{16} \mathrm{O} \\
{[\text { per mil] }}\end{array}$ & $\begin{array}{c}\mathrm{NO}_{3}^{-} \\
{[\mu \mathrm{mol} / \mathrm{L}]}\end{array}$ & $\begin{array}{c}\mathrm{NO}_{2}^{-} \\
{[\mu \mathrm{mol} / \mathrm{L}]}\end{array}$ & $\begin{array}{c}\mathrm{F}^{-} \\
{[\mu \mathrm{mol} / \mathrm{L}]}\end{array}$ & $\begin{array}{c}\mathrm{Cl}^{-} \\
{[\mu \mathrm{mol} / \mathrm{L}]}\end{array}$ & $\begin{array}{c}\mathrm{SO}_{4}^{2-} \\
{[\mu \mathrm{mol} / \mathrm{L}]}\end{array}$ & $\begin{array}{c}\mathrm{PO}_{4}^{3-} \\
{[\mu \mathrm{mol} / \mathrm{L}]}\end{array}$ \\
\hline 1527 SGT 16 to 1527 SGT 17 NOV 2009 & 27.19 & 56.16 & 1.18 & 0.96 & N/A & 2.28 & 1.22 & N/A \\
\hline 1539 SGT 17 to 1539 SGT 18 NOV 2009 & 9.02 & 62.37 & 1.2 & 0.54 & N/A & 2.35 & 1.75 & N/A \\
\hline 1542 SGT 18 to 1542 SGT 19 NOV 2009 & 21.36 & 25.54 & 0.2 & N/A & N/A & 0.46 & N/A & N/A \\
\hline 1818 SGT 19 to 1818 SGT 20 NOV 2009 & 7.78 & 21.17 & 0.23 & N/A & N/A & 0.7 & N/A & N/A \\
\hline 1835 SGT 20 to 1835 SGT 21 NOV 2009 & N/A & N/A & N/A & N/A & N/A & 0.23 & N/A & N/A \\
\hline 1908 SGT 21 to 1908 SGT 22 NOV 2009 & 16.64 & 41.91 & 0.62 & 0.46 & N/A & 1.6 & 0.33 & N/A \\
\hline $\begin{array}{l}1709 \text { SGT } 08 \text { to } 1709 \text { SGT } 12 \text { FEB } 2010 \\
\text { (Official CHINESE NEW YEAR was } \\
\text { from SUN } 14 \text { to TUE } 16 \text { FEB 2010) }\end{array}$ & -6.97 & 56.14 & 17.89 & 2.17 & 2.648 & 24.23 & 13.54 & 2.496 \\
\hline 1712 SGT 12 to 1712 SGT 16 FEB 2010 & -7.99 & 56.75 & 8.18 & 0.93 & 0.037 & 22.17 & 7.34 & N/A \\
\hline 1713 SGT 16 to 1713 SGT 20 FEB 2010 & -6.74 & 59.18 & 10.48 & N/A & 0.784 & 30.48 & 9.2 & N/A \\
\hline 1322 SGT 16 to 1322 SGT 20 JUL 2010 & 9.74 & 34.46 & 6.23 & 1.44 & 0.96 & 7.84 & 22.65 & N/A \\
\hline 1325 SGT 20 to 1325 SGT 24 JUL 2010 & 8.03 & 35.11 & 9.01 & N/A & N/A & 13.93 & 20.46 & N/A \\
\hline 1325 SGT 24 to 1325 SGT 28 JUL 2010 & 5.67 & 61.12 & 3.73 & N/A & N/A & 5.54 & 10.22 & N/A \\
\hline Average & 7.781 & 45.96 & 5.13 & 1.08 & 1.10 & 9.23 & 8.00 & 2.49 \\
\hline Standard deviation & 12.85 & 15.60 & 6.14 & 0.63 & 1.10 & 11.69 & 8.07 & N/A \\
\hline Variance & 165.26 & 243.54 & 37.70 & 0.40 & 1.21 & 136.71 & 65.17 & N/A \\
\hline Range & 35.18 & 41.2 & 17.69 & 1.71 & 2.61 & 30.25 & 22.32 & 0 \\
\hline Minimum value & -7.99 & 21.17 & 0.2 & 0.46 & 0.037 & 0.23 & 0.33 & 2.49 \\
\hline Maximum value & 27.19 & 62.37 & 17.89 & 2.17 & 2.648 & 30.48 & 22.65 & 2.49 \\
\hline Total & 70.03 & 413.68 & 46.21 & 6.5 & 4.429 & 92.34 & 56.03 & 2.49 \\
\hline Number of sample & 9 & 9 & 9 & 6 & 4 & 10 & 7 & 1 \\
\hline
\end{tabular}

\section{TABLE-2}

STABLE ISOTOPE RATIO AND ANION CONCENTRATION OF AEROSOL (PM 4.5) (5 L/min) AT FAIRBANKS

INTERNATIONAL AIRPORT (N: $64^{\circ} 50.116 \mathrm{~min}$, W: $147^{\circ} 49.747 \mathrm{~min}$, ALTITUDE: 143.4 meter) IN FAIRBANKS ALASKA U.S.A.

\begin{tabular}{|c|c|c|c|c|c|c|c|c|}
\hline $\begin{array}{c}\text { Sampling Date and Time (Alaska Standard } \\
\text { Time = AST = UTC }-9 \text { h; Alaska Daylight } \\
\text { Saving Time }=\text { ADT }=\text { UTC }-8 \text { h) }\end{array}$ & $\begin{array}{l}\delta^{15} \mathrm{~N} /{ }^{14} \mathrm{~N} \\
\text { [per mil] }\end{array}$ & $\begin{array}{l}\delta^{18} \mathrm{O} /{ }^{16} \mathrm{O} \\
\text { [per mil] }\end{array}$ & $\begin{array}{c}\mathrm{NO}_{3}^{-} \\
{[\mu \mathrm{mol} / \mathrm{L}]}\end{array}$ & $\begin{array}{c}\mathrm{NO}_{2}^{-} \\
{[\mu \mathrm{mol} / \mathrm{L}]}\end{array}$ & $\begin{array}{c}\mathrm{F}^{-} \\
{[\mu \mathrm{mol} / \mathrm{L}]}\end{array}$ & $\begin{array}{c}\mathrm{Cl}^{-} \\
{[\mu \mathrm{mol} / \mathrm{L}]}\end{array}$ & $\begin{array}{c}\mathrm{SO}_{4}^{2-} \\
{[\mu \mathrm{mol} / \mathrm{L}]}\end{array}$ & $\begin{array}{c}\mathrm{PO}_{4}^{3-} \\
{[\mu \mathrm{mol} / \mathrm{L}]}\end{array}$ \\
\hline 1414 AST 02 to 1414 AST 03 JAN 2010 & -24.1 & 35.6 & N/A & N/A & 0.18 & 0.48 & N/A & 1.2 \\
\hline 1417 AST 03 to 1417 AST 04 JAN 2010 & -9.3 & 26.9 & 0.26 & N/A & 1.73 & N/A & N/A & N/A \\
\hline 1421 AST 04 to 1421 AST 05 JAN 2010 & -11.3 & 43.7 & 0.22 & N/A & N/A & 0.72 & N/A & 1.68 \\
\hline 1711 ADT 01 to 1710 ADT 03 APR 2010 & 2.4 & 29.9 & 2.05 & N/A & 1.33 & 11.07 & 1.34 & N/A \\
\hline 1712 ADT 03 to 1712 ADT 05 APR 2010 & 5.1 & 38.8 & 0.93 & N/A & 1.07 & 11.17 & 1.72 & N/A \\
\hline 1716 ADT 07 to 1716 ADT 09 APR 2010 & N/A & N/A & N/A & N/A & 0.021 & 3.15 & 0.53 & N/A \\
\hline 1010 ADT 21 to 1010 ADT 23 SEP 2010 & 2.4 & 70 & N/A & N/A & N/A & 1.1 & N/A & N/A \\
\hline 1012 ADT 23 to 1012 ADT 25 SEP 2010 & 4.1 & 56.3 & N/A & N/A & N/A & 0.52 & N/A & N/A \\
\hline 1014 ADT 25 to 1014 ADT 27 SEP 2010 & 4.6 & 57 & N/A & N/A & N/A & N/A & N/A & N/A \\
\hline Average & -2.7 & 42.977778 & 0.934 & N/A & 0.72273 & 4.15875 & 1.19667 & 1.44 \\
\hline Standard deviation & 10.05062 & 15.053885 & 0.7559 & N/A & 0.74907 & 4.57801 & 0.60781 & 0.33941 \\
\hline Variance & 101.015 & 226.61944 & 0.5714 & N/A & 0.5611 & 20.9582 & 0.36943 & 0.1152 \\
\hline Minimum value & -24.1 & 26.9 & 0.22 & 0 & 0.0054 & 0.48 & 0.53 & 1.2 \\
\hline Maximum value & 5.1 & 70 & 2.05 & 0 & 1.73 & 11.17 & 1.72 & 1.68 \\
\hline Total & -24.3 & 386.8 & 4.67 & 0 & 4.3364 & 33.27 & 3.59 & 2.88 \\
\hline Number of sample & 9 & 9 & 5 & 0 & 6 & 8 & 3 & 2 \\
\hline
\end{tabular}

was +42.97 [per mil], very similar to the average value in Singapore, which was +46.36 [per mil] (Table-3). In summary, comparison of the Fairbanks samples and the Singapore samples only showed a latitude effect for nitrogen stable isotopes (both in foliage and in nitric-oxide substances within the aerosol samples).

In order to understand the effects of neutron bombardment on stable isotopes, it is necessary to refer to the laws governing the binding of the atomic nucleus ${ }^{10}$. There are certain nucleons $(2,8,20,28,50,82,126)$ that are more tightly bound than others; this is the origin of the shell model. Even numbers of nucleons are more tightly bound than odd numbers of nucleons.

Hence ${ }^{14} \mathrm{~N}$ is more easily broken than ${ }^{15} \mathrm{~N}$. The proton number and the neutron number of ${ }^{14} \mathrm{~N}$ are both 7 . The proton number of ${ }^{15} \mathrm{~N}$ is also 7 , but its neutron number is 8 (Table-4). Thus a nuclear chemical reaction in which ${ }^{14} \mathrm{~N}$ and a neutron (n) produce the ${ }^{14} \mathrm{C}$ radioisotope is known to occur in the atmosphere, especially at altitudes between 30,000 feet and 50,000 feet $(9000-15,000 \mathrm{~m})^{11-16}$.

$$
{ }_{0}^{1} \mathrm{n}+{ }_{7}^{14} \mathrm{~N} \rightarrow{ }_{6}^{14} \mathrm{C}+{ }_{1}^{1} \mathrm{H}
$$


TABLE-3

STABLE ISOTOPE RATIOS IN AEROSOL (PM 4.5) (5 L/min) AND FOLIAGE AT NATIONAL UNIVERSITY OF SINGAPORE (N: $1^{\circ} 18$ min; E: $103^{\circ} 46$ min; ALTITUDE: 67.0 meter), SINGAPORE AND FAIRBANKS INTERNATIONAL AIRPORT (N: $64^{\circ} 50.116 \mathrm{~min}$, W: $147^{\circ} 49.747 \mathrm{~min}$, ALTITUDE: 143.4 meter) FAIRBANKS ALASKA U.S.A.

Sampling place, date and time (Singapore Time $=$ SGT $=$ UTC $+8 \mathrm{~h}$ ) (Alaska Standard Time = AST $=$ UTC -9 $\mathrm{h}$; Alaska Daylight Saving Time $=$ ADT $=$ UTC $-8 \mathrm{~h}$ ) $\begin{array}{llll}\delta^{13} \mathrm{C} /{ }^{12} \mathrm{C} & \delta^{15} \mathrm{~N} /{ }^{14} \mathrm{~N} & \delta^{13} \mathrm{C} /{ }^{12} \mathrm{C} & \delta^{15} \mathrm{~N} /{ }^{14} \mathrm{~N} \\ {[\text { per mill }} & {[\text { per mil] }}\end{array}$ [per mil] [per mil] [per mil] [per mil]

in foliage in foliage $\begin{array}{cccc}\text { needles } & \text { needles } & \text { of } & \text { of } \\ \text { (foliage) } & \text { (foliage) } & \text { Samanea } & \text { Samanea }\end{array}$

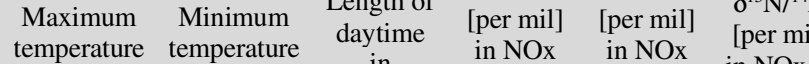
place $\left({ }^{\circ} \mathrm{C}\right)$ place $\left({ }^{\circ} \mathrm{C}\right)$ Abies of Abies

gapore

\section{Singapore}

16-Nov-09 $\quad \mathrm{S} 18.70$

1527 SGT 16 to 1527 SGT 17 NOV 2009 in Singapore

1818 SGT 19 to 1818 SGT 20 NOV 2009 in Singapore $\quad 20-N o v-09 \quad$ S 19.67

1908 SGT 21 to 1908 SGT 22 NOV 2009 in Singapore 22-Nov-09 S 20.10

1414 AST 02 to 1414 AST 03 JAN 2010 in Fairbanks $\quad$ 3-Jan-10 S 22.85

1417 AST 03 to 1417 AST 04 JAN 2010 in Fairbanks $\quad$ 4-Jan-10 S 22.75

1421 AST 04 to 1421 AST 05 JAN 2010 in Fairbanks 5-Jan-10 S 22.63

1709 SGT 08 to 1709 SGT 12 FEB 2010 in Singapore; 12-Feb-10 S 13.78

(Official CHINESE NEW YEAR was from SUN 14 to

TUE 16 FEB 2010)

1712 SGT 12 to 1712 SGT 16 FEB 2010 in Singapore

Singapore

1713 SGT 16 to 1713 SGT 20 FEB 2010 in Singapore

1711ADT 01 to 1710 ADT 03 APR 2010 in Fairbanks

1712 ADT 03 to 1712 ADT 05 APR 2010 in Fairbanks

Fairbanks

1714 ADT 05 to 1714 ADT 07 APR 2010 in Fairbanks

1322 SGT 16 to 1322 SGT 20 JUL 2010 in Singapore

1325 SGT 20 to 1325 SGT 24 JUL 2010 in Singapore

Singapore

1325 SGT 24 to 1325 SGT 28 JUL 2010 in Singapore

Fairbanks

1010 ADT 21 to 1010 ADT 23 SEP 2010 in Fairbanks

Fairbanks

16-Feb-10 S 12.43

18-Feb-10 S 11.73

20-Feb-10 S 11.03

3-Apr-10 N 5.18

5-Apr-10 N 5.93

6-Apr-10 N 6.32

7-Apr-10 N 6.70

20-Jul-10 N 20.71

24-Jul-10 N 19.9

27-Jul-10 N 19.27

28-Jul-10 N 19.05

22-Sep-10 N 0.43

23-Sep-10 N 0.05

24-Sep-10 S 0.33

1012 ADT 23 to 1012 ADT 25 SEP 2010 in Faibanks 25-Sep-10 S 0.72

1014 ADT 25 to 1014 ADT 27 SEP 2010 in Fairbanks 27-Sep-10 S 1.50

$4.11 \quad 56.29$

\begin{tabular}{l}
$\mathrm{N} / \mathrm{A}$ \\
$\mathrm{N} / \mathrm{A}$ \\
$\mathrm{N} / \mathrm{A}$ \\
$\mathrm{N} / \mathrm{A}$ \\
$\mathrm{N} / \mathrm{A}$ \\
$\mathrm{N} / \mathrm{A}$ \\
$\mathrm{N} / \mathrm{A}$ \\
$\mathrm{N} / \mathrm{A}$ \\
-17 \\
$\mathrm{~N} / \mathrm{A}$ \\
\\
$\mathrm{N} / \mathrm{A}$ \\
$\mathrm{N} / \mathrm{A}$ \\
$\mathrm{N} / \mathrm{A}$ \\
$\mathrm{N} / \mathrm{A}$ \\
$\mathrm{N} / \mathrm{A}$ \\
-14.3 \\
-13.9 \\
$\mathrm{~N} / \mathrm{A}$ \\
$\mathrm{N} / \mathrm{A}$ \\
$\mathrm{N} / \mathrm{A}$ \\
$\mathrm{N} / \mathrm{A}$ \\
-28.8 \\
-28.8 \\
-29.4 \\
-30.1 \\
$\mathrm{~N} / \mathrm{A}$ \\
-23.186 \\
7.6693 \\
58.8181 \\
16.2 \\
-30.1 \\
-13.9 \\
-16.3 \\
7 \\
\hline
\end{tabular}

N/A N/A

N/A

N/A

N/A N/A N/A

N/A N/A N/A N/A

N/A $\quad$ N/A $\quad$ N/A $\quad$ N/A

N/A N/A N/A N N

N/A N/A N/A N/A

N/A N/A N/A N/A

$\begin{array}{llll}-17 & -7.1 & \mathrm{~N} / \mathrm{A} & \mathrm{N} / \mathrm{A}\end{array}$

N/A

N/A

N/A

N/A $\quad$ N/A $\quad-15.2 \quad 2.6$

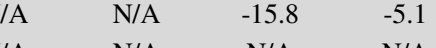

N/A $\quad$ N/A $\quad$ N/A $\quad N / A$

N/A N/A N/A $\quad$ N/A

$-14.3-6.4 \quad \mathrm{~N} / \mathrm{A} \quad \mathrm{N} / \mathrm{A}$

$\begin{array}{llll}-13.9 & 1.8 & \mathrm{~N} / \mathrm{A} & \mathrm{N} / \mathrm{A}\end{array}$

$\begin{array}{lll}1.8 & \text { N/A } & \text { N/A } \\ \text { N/A } & \text { N/A } & \text { N/A }\end{array}$

$\begin{array}{lll}\text { N/A } & \text { N/A } & \text { N/A } \\ \text { N/A } & -32.7 & -1.1\end{array}$

N/A $\quad-32.7 \quad-1.6$

N/A N/A N/A

$\begin{array}{lll}-0.5 & \mathrm{~N} / \mathrm{A} & \mathrm{N} / \mathrm{A} \\ -0.6 & \mathrm{~N}\end{array}$

$\begin{array}{lll}-0.5 & \mathrm{~N} / \mathrm{A} & \mathrm{N} / \mathrm{A} \\ -0.6 & \mathrm{~N} / \mathrm{A} & \mathrm{N} / \mathrm{A}\end{array}$

$-0.2 \quad N / A \quad N / A$

N/A N/A

N/A N/A N/A N/A

27.03

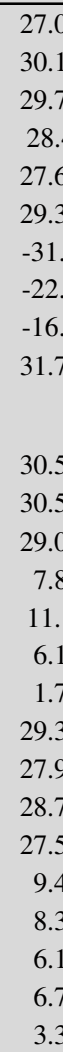

N/A

N/A

N/A
N/A
N/A

N/A

N/A

N/A
27.19
9.02

24.16
25.38

12.05

12.05

12.05

12.05

12.05

N/A

N/A

N/A

$-24.11$

$\begin{array}{ll}4.2 & -9.28 \\ 4.28 & -11.26\end{array}$

4.28

12.07

$-11.26$

N/A

$\begin{array}{ll}30.53 & 25.57\end{array}$

$30.52 \quad 25.87$

12.07

12.07

12.07

13.85

14.07

14.18

14.3

14.3
12.18

12.18
12.18

12.16

12.16

12.16
12.26

12.26
12.17

12.05

11.95

$-8.9$

Average

11.7

Variance

Range

Minimum value

Maximum value

Total

Number of sample
N/A

N/A

N/A

2.43
5.1

N/A

1.76

N/A

N/A

N/A

N/A

2.38
N/A

N/A

$4.6 \quad 57$

$-2.6967$

$100.935 \quad 226.618$

$\begin{array}{lll}29.21 & 43.12 & 35.18\end{array}$

$\begin{array}{lll}-24.11 & 26.87 & -7.99\end{array}$

$\begin{array}{lll}5.1 & 69.99 & 27.19\end{array}$ $\begin{array}{ccc}-24.27 & 386.71 & 83.7\end{array}$

83.73
11

$\begin{array}{cc}\text { N/A } & \text { N/A } \\ 56.16 & \mathrm{~N} / \mathrm{A} \\ 62.37 & \mathrm{~N} / \mathrm{A} \\ 25.54 & \mathrm{~N} / \mathrm{A} \\ 21.17 & \mathrm{~N} / \mathrm{A} \\ 41.91 & \mathrm{~N} / \mathrm{A} \\ \mathrm{N} / \mathrm{A} & \mathrm{N} / \mathrm{A} \\ \mathrm{N} / \mathrm{A} & \mathrm{N} / \mathrm{A} \\ \mathrm{N} / \mathrm{A} & -17 \\ 56.14 & \mathrm{~N} / \mathrm{A} \\ & \\ 56.75 & \mathrm{~N} / \mathrm{A} \\ \mathrm{N} / \mathrm{A} & \mathrm{N} / \mathrm{A} \\ 59.18 & \mathrm{~N} / \mathrm{A} \\ \mathrm{N} / \mathrm{A} & \mathrm{N} / \mathrm{A} \\ \mathrm{N} / \mathrm{A} & \mathrm{N} / \mathrm{A} \\ \mathrm{N} / \mathrm{A} & -14.3 \\ \text { N/A } & -13.9 \\ 34.46 & \mathrm{~N} / \mathrm{A} \\ 35.11 & \mathrm{~N} / \mathrm{A} \\ \text { N/A } & \mathrm{N} / \mathrm{A} \\ 61.12 & \mathrm{~N} / \mathrm{A} \\ \text { N/A } & -28.8 \\ \text { N/A } & -28.8 \\ \text { N/A } & -29.4 \\ \text { N/A } & -30.1 \\ \text { N/A } & \mathrm{N} / \mathrm{A} \\ 46.3555 & -23.18 \\ 15.1465 & 7.669 \\ 229.415 & 58.818 \\ 41.2 & 16.2 \\ 21.17 & -30.1 \\ 62.37 & -13.9 \\ 509.91 & -162 \\ 11 & \\ \end{array}$

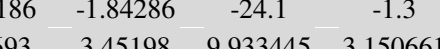

$\begin{array}{lll}9.933445 & -3.150661\end{array}$

$\begin{array}{cccc}7.8181 & 11.9162 & 98.67333 & 9.926667 \\ 6.2 & 8.9 & 17.5 & 7.7\end{array}$

$\begin{array}{llll}-7.1 & -7.1 & -32.7 & -5.1\end{array}$

$\begin{array}{llll}-13.9 & 1.8 & -15.2 & 2.6\end{array}$

7

-12.9
7

4 


\section{TABLE-4}

CHARACTERISATIONS OF CARBON (C), NITOROGEN (N) AND OXYGEN (O) STABLE ISOTOPES FOR THIS STUDY

\begin{tabular}{lcccccc}
\hline \multicolumn{1}{c}{ Stable isotope } & ${ }^{12} \mathrm{C}$ & ${ }^{13} \mathrm{C}$ & ${ }^{14} \mathrm{~N}$ & ${ }^{15} \mathrm{~N}$ & ${ }^{16} \mathrm{O}$ & ${ }^{18} \mathrm{O}$ \\
\hline Atomic number & 6 & 6 & 7 & 7 & 7 & 8 \\
Proton number & 6 & 6 & 7 & 7 & 8 & 8 \\
Mass number & 12 & 13 & 14 & 15 & 16 & 18 \\
Neutron number & 6 & 7 & 7 & 8 & 8 & 10 \\
\hline
\end{tabular}

In contrast, there is no known nuclear chemical reaction between ${ }^{15} \mathrm{~N}$ and a neutron (n) because ${ }^{15} \mathrm{~N}$ is more tightly bound than ${ }^{14} \mathrm{~N}$ (due to the fact that ${ }^{15} \mathrm{~N}$ has a neutron number of 8). Therefore only ${ }^{14} \mathrm{~N}$ is affected by neutron bombardment from the sun and from cosmic rays. Thus ${ }^{14} \mathrm{~N}$ is converted into the ${ }^{14} \mathrm{C}$ radioisotope and the relative amount of ${ }^{15} \mathrm{~N}$ in the stable isotope ratio is increased. The latitude effect on nitrogen stable isotope ratios (both in the foliage and in the nitric-oxide substances within the aerosol samples) should be affected by these principles. Lower latitudes such as Singapore tend to have higher atmospheric temperatures than do higher latitudes such as Fairbanks, Alaska. Higher atmospheric temperatures generate stronger updrafts, allowing aerosols to climb to higher altitudes. At these higher altitudes, neutrons are more abundant than at lower altitudes. Consequently, at lower latitudes there are more active conversions from ${ }^{14} \mathrm{~N}$ to ${ }^{14} \mathrm{C}$ by neutron bombardment. This is the mechanism by which nitrogen stable isotope ratios $\left(\delta^{15 / 14} \mathrm{~N}\right)$, both in foliage and in nitric-oxide substances within the aerosol samples, are increased at lower latitudes.

In Singapore, day length as well maximum and minimum temperature remain nearly constant throughout the year. If $\delta^{15 /}$ ${ }^{14} \mathrm{~N}$ was correlated with these factors only, it should not show substantial change throughout the year (Table-3, Figs. 1-4). However, $\delta^{15 / 14} \mathrm{~N}$ in Singapore does vary considerably over the course of a year. These variations in $\delta^{15 / 14} \mathrm{~N}$ in nitric-oxide substances within Singapore aerosol samples were clearly correlated with declination. $\delta^{15 / 14} \mathrm{~N}$ in nitric-oxide substances within the aerosol samples reached maximum values at declinations $c a .20^{\circ} \mathrm{N}$ and $20^{\circ} \mathrm{S}$. Minimum values were reached at ca. $0^{\circ} \mathrm{N}$ and $\mathrm{S}$ (Fig. 5). Singapore is located at $1.3^{\circ} \mathrm{N}$, almost at the equator $\left(0^{\circ} \mathrm{N}\right.$ and $\left.\mathrm{S}\right)$. Therefore, similar declination values indicate similar positions of the sun from Singapore. This allowed us to confirm the correlation between declination and $\delta^{15 / 14} \mathrm{~N}$ in nitric-oxide substances within aerosols. Another mechanism by which latitude affects stable isotope ratios concerns the deflection of cosmic rays. Cosmic radiation decreases with decreasing latitude, reaching a minimum at the equator. This is because the Earth's geomagnetic field (specifically the Van Allen radiation belt) deflects cosmic rays most effectively at the equator ${ }^{17}$. When declination approaches $0^{\circ} \mathrm{N}$ and $\mathrm{S}$, cosmic radiation to Singapore decreases. Therefore conversion from ${ }^{14} \mathrm{~N}$ into ${ }^{14} \mathrm{C}$ decreases, and thus the relative amount of ${ }^{15} \mathrm{~N}$ in the stable isotope ratio also decreases. On

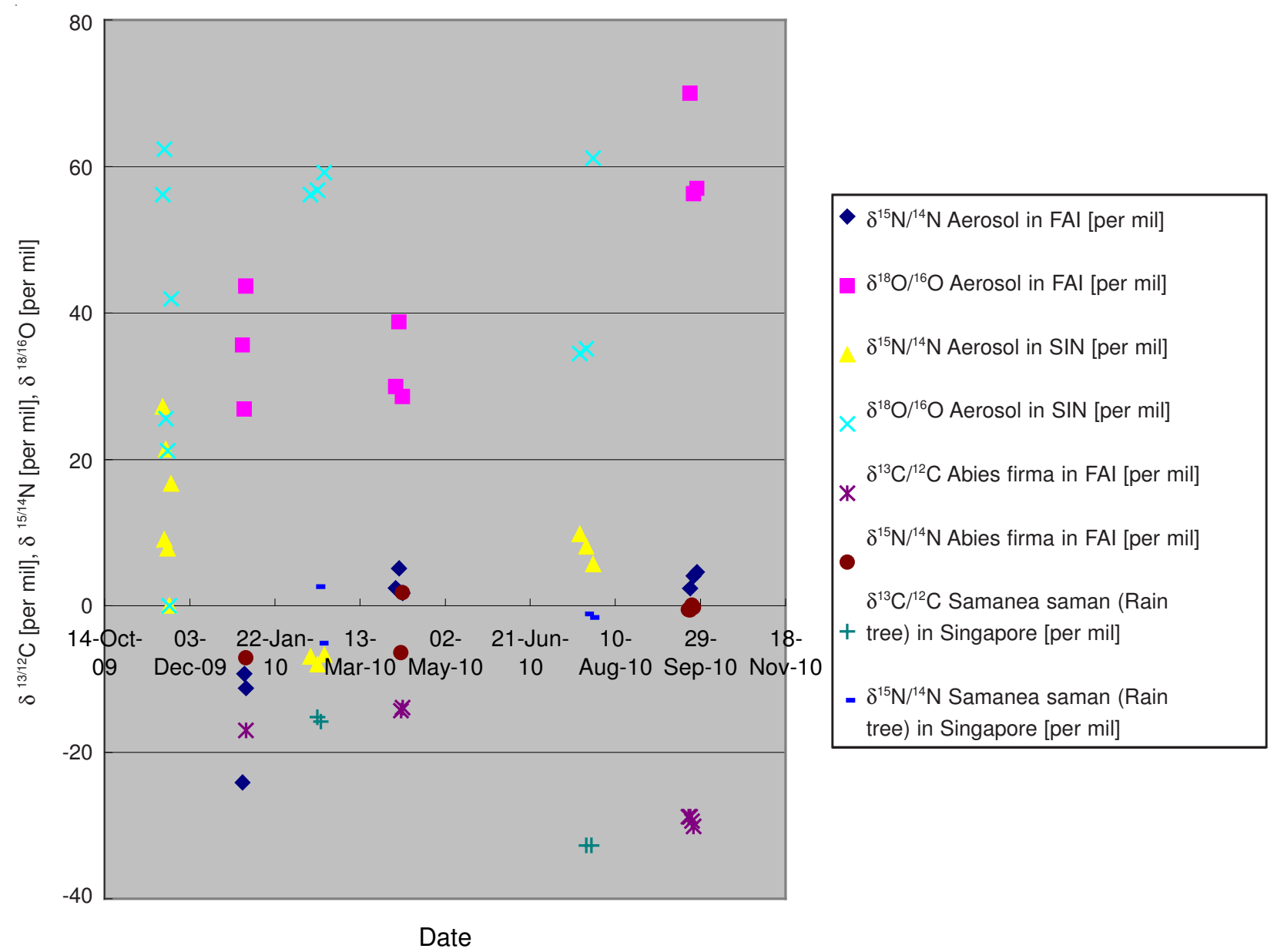

Fig. 1. Date vs. isotope ratios (FAI: Fairbanks, Alaska; latitude: 64.84 degree north), (SIN: Singapore; latitude: 1.3 degree north) 


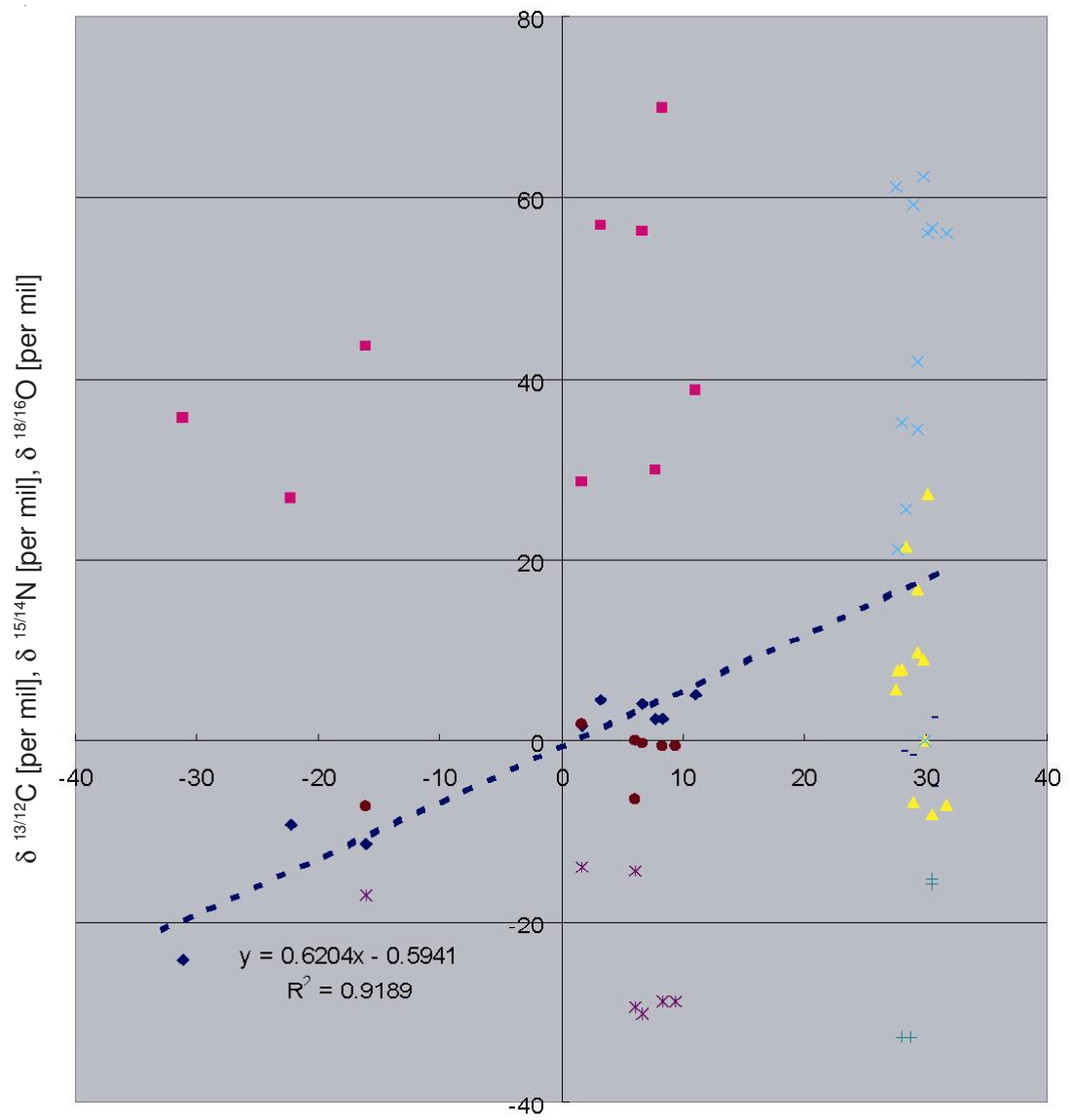

- ${ }^{15} \mathrm{~N} /{ }^{14} \mathrm{~N}$ Aerosol in FAl [per mil]

- ${ }^{18} \mathrm{O} /{ }^{16} \mathrm{O}$ Aerosol in FAl [per mil]

${ }^{15} \mathrm{~N} /{ }^{14} \mathrm{~N}$ Aerosol in SIN [per mil]

${ }^{18} \mathrm{O} /{ }^{16} \mathrm{O}$ Aerosol in SIN [per mil]

$* \quad{ }^{13} \mathrm{C} /{ }^{12} \mathrm{C}$ Abies firma in FAl [per mil]

- ${ }^{15} \mathrm{~N} /{ }^{14} \mathrm{~N}$ Abies firma in FAl [per mil]

$+{ }^{13} \mathrm{C} /{ }^{12} \mathrm{C}$ Samanea saman (Rain tree) in Singapore [per mil]

- ${ }^{15} \mathrm{~N} /{ }^{14} \mathrm{~N}$ Samanea saman (Rain tree) in Singapore [per mil]

- - ${ }^{15} \mathrm{~N} /{ }^{14} \mathrm{~N}$ Aerosol in FAl [per mil]

Maximum temperature $\left({ }^{\circ} \mathrm{C}\right)=\mathrm{x}, \mathrm{R}=$ Coefficient of correlation

Fig. 2. Maximum temperture $v s$. isotope ratios (FAI: Fairbanks, Alaska; latitude: 64.84 degree north), (SIN: Singapore; latitude: 1.3 degree north)

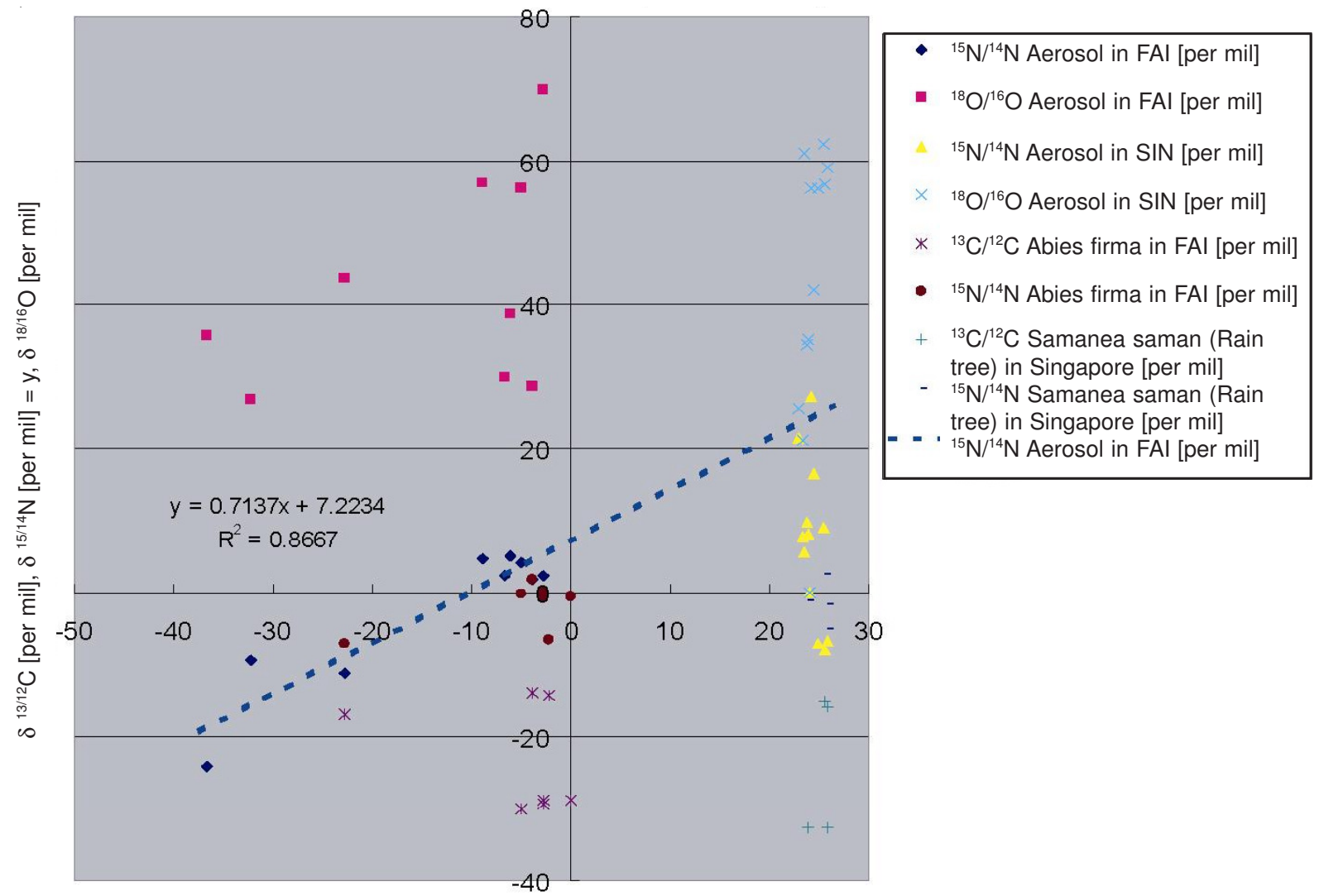

Maximum temperature $\left({ }^{\circ} \mathrm{C}\right)=\mathrm{x}, \mathrm{R}=$ Coefficient of correlation

Fig. 3. Minimum temperature vs. isotope ratios (FAI: Fairbanks, Alaska; latitude: 64.84 degree north), (SIN: Singapore; latitude: 1.3 degree north) 


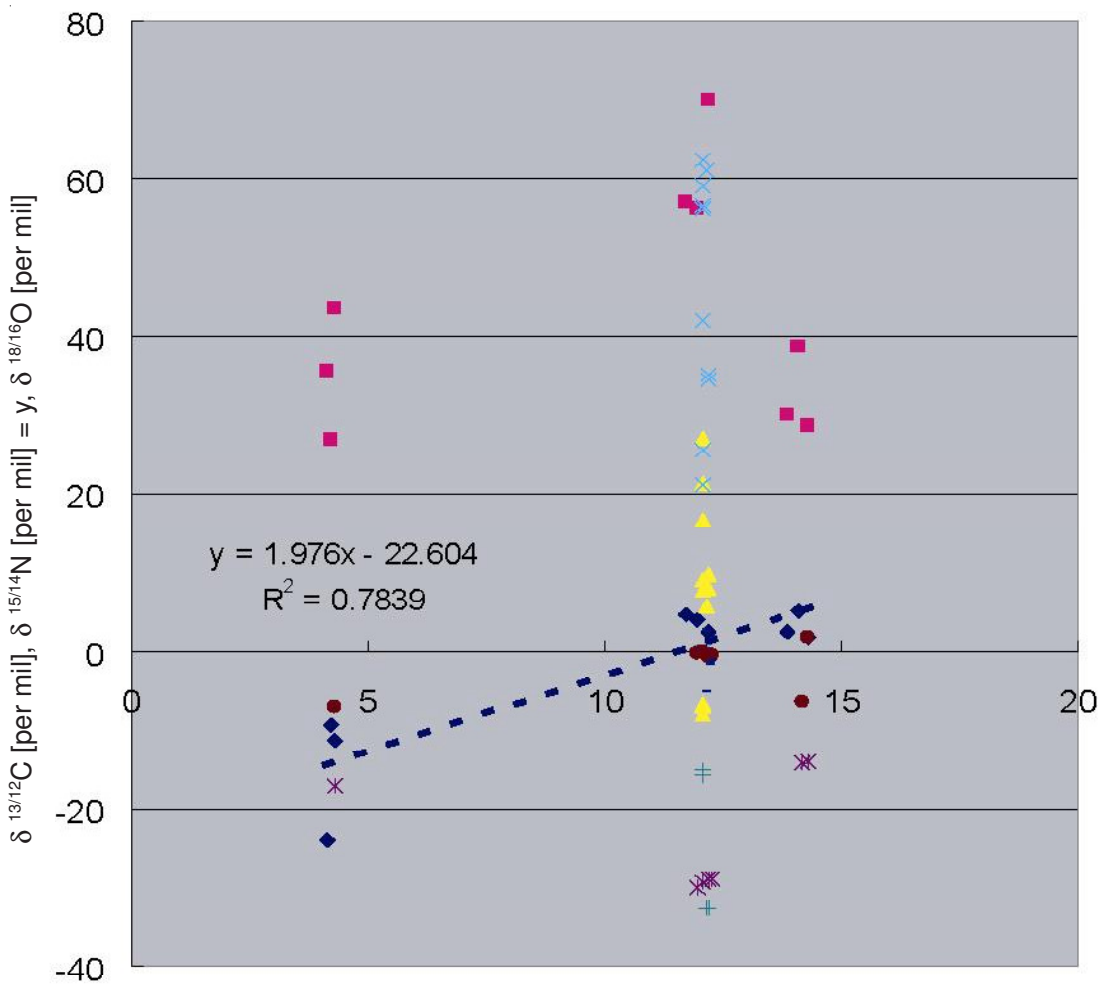

- ${ }^{15} \mathrm{~N} /{ }^{14} \mathrm{~N}$ Aerosol in FAl [per mil]

- ${ }^{18} \mathrm{O} /{ }^{16} \mathrm{O}$ Aerosol in FAl [per mil]

${ }^{15} \mathrm{~N} /{ }^{14} \mathrm{~N}$ Aerosol in SIN [per mil]

$\times{ }^{18} \mathrm{O} /{ }^{16} \mathrm{O}$ Aerosol in SIN [per mil]

$*{ }^{13} \mathrm{C} /{ }^{12} \mathrm{C}$ Abies firma in FAl [per mil]

- ${ }^{15} \mathrm{~N} /{ }^{14} \mathrm{~N}$ Abies firma in FAl [per mil]

$+{ }^{13} \mathrm{C} /{ }^{12} \mathrm{C}$ Samanea saman (Rain tree) in Singapore [per mil]

- ${ }^{15} \mathrm{~N} /{ }^{14} \mathrm{~N}$ Samanea saman (Rain tree) in Singapore [per mil]

- - ${ }^{15} \mathrm{~N} /{ }^{14} \mathrm{~N}$ Aerosol in FAl [per mil]

Length of daytime $(h)=x, R=$ Coefficient of corrleation

Fig. 4. Length of daytime vs. isotope ratios (FAI: Fairbanks, Alaska; latitude: 64.84 degree north), (SIN: Singapore; latitude: 1.3 degree north)

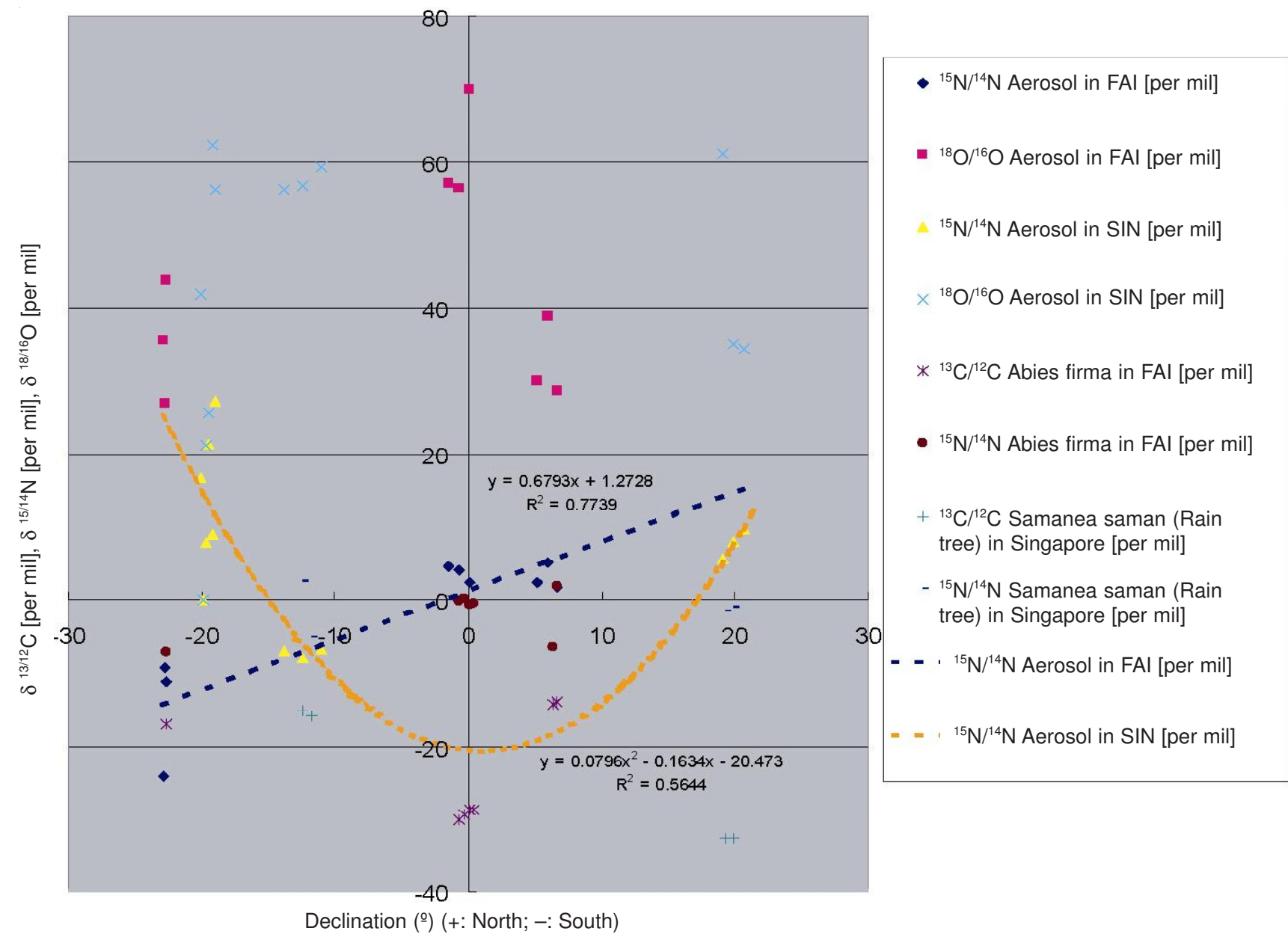

Fig. 5. Declination vs. isotope ratios (FAI: Fairbanks, Alaska; latitude: 64.84 degree north), (SIN: Singapore; latitude: 1.3 degree north) 
the other hand, as declination approaches $20^{\circ} \mathrm{N}$ and $\mathrm{S}$, cosmic radiation to Singapore increases, and accordingly the relative amount of ${ }^{15} \mathrm{~N}$ in the stable isotope ratio also increases. The results of this study were closely aligned with these explanations of the relationship between declination and values of $\delta^{15 / 14} \mathrm{~N}$ in nitric-oxide substances within the aerosol samples.

Fig. 5 shows a significant positive linear relationship between declination and $\delta^{15 / 14} \mathrm{~N}$ in nitric-oxide substances from the aerosol samples in Fairbanks. However, unlike Singapore, Fairbanks also showed distinct trends for maximum and minimum atmospheric temperature and day length. In higherlatitude regions such as Fairbanks, declination has a greater effect on maximum and minimum atmospheric temperature and day length than it does in lower-latitude regions such as Singapore. Longer day lengths in Fairbanks contribute to higher atmospheric temperatures, which in turn propel nitricoxide substances within the aerosol to higher altitudes where they are exposed to greater numbers of neutrons. Consequently, it was observed that the value of $\delta^{15 / 14} \mathrm{~N}$ in nitric-oxide substances within the aerosol samples in Fairbanks increased with increasing declination, due to more active conversions from ${ }^{14} \mathrm{~N}$ to ${ }^{14} \mathrm{C}$ by neutron bombardment.

\section{Conclusion}

The knowledge and insights gained in this study are discussed below.

(1) It is known general tendency as a latitude effect that nitrogen stable isotope ratios $\delta^{15 / 14} \mathrm{~N}$ in the foliage in lower latitude has higher than that of in higher latitude ${ }^{9}$. Average value of $\delta^{15 / 14} \mathrm{~N}$ in foliage in Fairbanks (latitude: 64.84 degree North) was -1.84 [per mil] versus average value of $\delta^{15 / 14} \mathrm{~N}$ in foliage in Singapore (latitude: 1.3 degree north) was -1.3 [per mil] on Table-3. It was subjected to this latitude effect clearly. However average value of $\delta^{13 / 12} \mathrm{C}$ in foliage in Fairbanks was -23.18 [per mil] versus average value of $\delta^{13 / 12} \mathrm{C}$ in foliage in Singapore was -24.1 [per mil] (Table-3). It was unclear tendency for $\delta^{13 / 12} \mathrm{C}$ in foliage between Fairbanks and Singapore. In addition average value of $\delta^{15 / 14} \mathrm{~N}$ in the nitricoxide substances within the aerosol samples in Fairbanks was -2.70 [per mil] versus average value of $\delta^{15 / 14} \mathrm{~N}$ in the nitricoxide substances within the aerosol samples in Singapore was +7.61 [per mil] (Table-3). It was also subjected to this latitude effect cleanly in spite of samples were not foliage, it was nitricoxide substances within the aerosol samples. Meanwhile average value of $\delta^{18 / 16} \mathrm{O}$ in the nitric-oxide substances within the aerosol samples in Fairbanks was +42.97 [per mil] whereas average value of $\delta^{18 / 16} \mathrm{O}$ in the nitric-oxide substances within the aerosol samples in Singapore was +46.36 [per mil] (Table-3). It was unclear tendency for $\delta^{18 / 16} \mathrm{O}$ in the nitricoxide substances within the aerosol samples between Fairbanks and Singapore. Therefore clearly latitude effect between Fairbanks (latitude: 64.84 degree north) and Singapore (latitude: 1.3 degree north) was only observed for nitrogen stable isotopes. both in the foliage and in nitric-oxide substances within the aerosol samples

(2) In Singapore it was also observed that values of $\delta^{15 /}$ ${ }^{14} \mathrm{~N}$ in nitric-oxide substances within the aerosol samples were clearly correlated with declination.
(3) The value of $\delta^{15 / 14} \mathrm{~N}$ in nitric-oxide substances within the aerosol samples in Fairbanks increased with increasing declination due to more active conversions from ${ }^{14} \mathrm{~N}$ to ${ }^{14} \mathrm{C}$ by neutron bombardment.

\section{ACKNOWLEDGEMENTS}

The author wishes to thank Neutron monitors of the Bartol Research Institute, University of Delaware in Newark, Delaware U.S.A. are supported by the National Science Foundation; Dr. Blake Moore, Alaska Climate Research Center in Fairbanks, Alaska, U.S.A,; Mr. Paul and Ms. Betty Baer, Owners of Golden North Motel in Fairbanks, Alaska, U.S.A.; Dr. Rajasekhar Balasubramanian, Professor, National University of Singapore (NUS) in Singapore; Dr. Jun He, Professor, The University of Nottingham Ningbo, China ; Dr. Candidate Betha Raghu Nus; Ms. Suryani Khamis, Visitor Services Officer, Singapore Botanic Gardens in Singapore; Dr.Yoichiro Hanaoka, the Director, the Solar Observatory of Japan; Ms. Tomoko Kimura, Owner of the website for Botanical Detail in Singapore; Masters of Agriculture Akiko Sakai, Masters of Agriculture Yuji Sasaki and Masters of Agriculture Yu Takebayashi, former graduate students, Tokyo University of Agriculture \& Technology (TUAT); Dr. Yunting Fang, Visiting Professor, TUAT; Dr. Shiro Hatakeyama, Professor, TUAT; Dr. Ryo Funada, Dean, The United Graduate School of Agricultural Science (UGSAS), TUAT; Dr. Masao Takayanagi, Deputy Dean, UGSAS, TUAT; Yukiya Fukuhara, Professor, University of Tsukuba S.H.S. at Sakado in Japan; and Sakie Katsura, Director General of the Nursing Department at Saiseikai Kanagawa-Ken Hospital for the Social Welfare Organization Saiseikai Imperial Gift Foundation Inc., in Japan for assisting with this study. The international standards used in this study were purchased from Shoko SI Science in Matsudo-Shi, Chiba-Ken, Japan in May 2008 by Dr. Muneoli Yoh, Associate Professor, TUAT.

\section{REFERENCES}

1. Y. Fang, K. Koba, X.M. Wang, D.Z. Wen, J. Li, Y. Takebayashi, X.Y. Liu and M. Yoh, Atmos. Chem. Phys., 11, 1313 (2011).

2. M. Samuel, J. Savarino, F.M. Markus, N. Yan, S. Bekki, J.W. Bottenheim and M.F. Jean, Science, 322, 730 (2008).

3. K. Baechmann, P. Ebert, I. Haag, T. Prokop and K. Steigerwald, Atmos. Environ., 30, 1019 (1996).

4. W.F. Libby, Phys. Rev., 69, 671 (1946).

5. J.W. Bieber, E. Eroshenko, P. Evenson, E.O. Flückiger and R. Kallenbach, Space Sci. Rev., 93, 1 (2010).

6. K.L. Casciotti, D.M. Sigman, M.G. Hastings, J.K. Böhlke and A. Hilkert, Anal. Chem., 74, 4905 (2002).

7. Y. Takebayashi, K. Koba, Y. Sasaki, Y. Fang and M. Yoh, Rapid Commun. Mass Spectrom., 24, 1001 (2010).

8. P. Richet, Y. Bottinga and M. Javoy, Ann. Rev. Earth Planet. Sci., 5, 65 (1977).

9. J.M. Craine, A.J. Elmore, M.P.M. Aidar, M. Bustamante, T.E. Dawson, E.A. Hobbie, A. Kahmen, M.C. Mack, K.K. McLauchlan, A. Michelsen, G.B. Nardoto, L.H. Pardo, J. Peñuelas, P.B. Reich, E.A.G. Schuur, W.D. Stock, P.H. Templer, R.A. Virginia, J.M. Welker and I.J. Wright, New Phytologist, 183, 980 (2009).

10. O. Haxel, J.H.D. Jensen and H.E. Suess, Phys. Rev., 75, 1766 (1949).

11. N. Feather, Proc. Royal Soc. London, Series A, 136, 830 (1932).

12. E. Fermi, Nature, 133, 757 (1934).

13. E. Fermi, Artifical Radioactivity Produced by Neutron Bombardment, Nobel Lecture, December 12, 1938 (1938).

14. W. Harkins, Phys. Rev., 44, 529 (1933).

15. C.B. Ramsey, Archaeometry, 50, 249 (2008).

16. E. Rutherford, Proc. Royal Soc. London, Series A, 97, 374 (1920).

17. J.A. Van Allen and L.A. Frank, Nature, 183, 430 (1959). 